\title{
ON THE WESTON CELL
}

\section{BY H. T. BARNES AND S. B. LUCAS}

Within the last few years a great deal of work has been done with the Weston cell to show that it is equal in reproducibility and constancy to the Clark cell, and that it is in every way a suitable standard of electromotive force. The great advantage which it possesses over the Clark cell is of course the small temperature coefficient making it unnecessary, except in very accurate work, to take account of the changes of E. M. F.

Experience has shown that the small initial differences between new cells are of the same order of magnitude for the two types of cell, which gives the Clark cell a considerable advantage in point of accuracy. In physical investigation, where the measurement of temperature is usually a matter of detail, it is of little importance whether a cell possesses a small or large temperature coefficient provided it is known.

What is required of a standard is greatest possible accuracy in construction, and constancy in initial variations between different cells at all temperatures, and for a reasonable length of time. It has been shown at the Reichsanstalt, and independently in this laboratory that the Clark cell follows the temperature changes of its E. M. F. with great precision. This is shown also when the two formulas which were deduced by Kahle and by Callendar and Barnes, using different types of cells, are compared.

Callendar and Barnes have shown in particular that the initial differences between cells are maintained at all temperatures to an order of accuracy approaching I part in roo,000. The true test of the reliability of a cell is the behavior of individual cells rather than the mean value of a large number. Initial differences do not seem to be so well preserved in the case of the Weston cell as for the Clark over an extended period, although it may yet be shown that the two are equal in this re- 
spect. There can be no question, as to the superiority of the Weston cell as a working standard, quite apart from its value in accurate physical investigation, and its general adoption can be only a question of time.

All forms of the Clark cell, containing a saturated solution, have the same temperature coefficient, the only type possessing a different one being the Carhart-Clark with dilute solution.

In the case of the Weston cell it seems that four coefficients are possible, depending on the state of the cadmium sulphate solution. In a previous paper by one $\mathrm{e}^{\mathrm{x}}$ of us it was pointed out that the type of cell known and described as the inverted cel1 ${ }^{2}$ appeared to possess a greater temperature change than the cells made and tested at the Reichsanstalt by Jaeger and Wachsmuth. ${ }^{3}$ At the same time one of the cells tested at that time, known as $\mathrm{Cd} \mathrm{H}$, was made after the pattern of Jaeger's cells. This cell, we found, possessed practically the same coefficient as the inverted. A I 4.7 percent amalgam was used for all these cells, and made from some cadmium rod which had been in the laboratory some time previously. When tested qualitatively this cadmium was found free from zinc.

In these first tests great irregularity was shown below $\mathrm{I} 5^{\circ} \mathrm{C}$, and in some cases a sudden change in E. M. F. seemed to indicate a change in the hydration of the cadmium sulphate in a way similar to the change observed by Callendar and Barnes ${ }^{4}$ for the Clark cell at $39^{\circ}$.

As originally stated, these first cells were made in order to verify the value of the Clark cell upon which the absolute value of the mechanical equivalent of heat measured by electrical means, ${ }^{5}$ was based. As a matter of interest, however, the temperature change was determined and found larger than that ob-

1 Jour. Phys. Chem. 4, 339 (Igoo).

3 B. A. Report, Toronto, I897, and the Electrician, 39, 68 (1897); 40, 165 (I897).

${ }^{3}$ Wied. Ann. 59, 575 (1896).

${ }^{4}$ Proc. Roy. Soc. 62, 148 (1897).

${ }^{5}$ Phil. Trans. AI99, I49 (I9O2). 
tained by Jaeger and Wachsmuth. It was not at all clear at that time why there should be such a large divergence in the results, for the only striking difference between our cells and those of Jaeger and Wachsmuth was in the use, both in the inverted and in the H-cell, of a mass of moist cadmium sulphate crystals in place of the saturated solution and crystals. The moist crystals were used on account of the great success attending the use of the same in the Clark "Crystal" cell.

Quite recently a large number of tests have been made by Jaeger and Lindeck ${ }^{x}$ with both old and new Weston cells in order to verify the original temperature formula proposed by Jaeger and Wachsmuth. ${ }^{2}$ These tests are very complete and show that for the cell with saturated solution as prepared in the Reichsanstalt, the temperature change of the E. M. F. may be accurately represented by the formula

$$
\mathrm{E}_{t}=\mathrm{E}_{20}-0.038(t-20)-0.00067(t-20)^{2},
$$

expressed in millivolts.

The first term only need be considered unless working over a wide range of Io or 20 degrees, and it may be stated that these cells possess an average change at ordinary temperatures of $0.003^{8}$ percent per degree. The temperature change observed for the inverted cells and $\mathrm{H}$-cell with moist crystals and $\mathrm{I} 4.7$ percent amalgam amounted to 0.0086 percent per degree, which, as Jaeger points out, is double the other value.

In order to arrive at a satisfactory explanation of this matter further tests were made by one of us in I $90 \mathrm{r}$ with the assistance of Mr. H. Lester Cooke, M.A. A test-tube form of cell was constructed similar to the Clark "crystal" cell. This consisted, briefly, of a paste of mercurous sulphate and cadmium sulphate with amalgamated platinum cathode in the bottom of the tube, and a mass of moist crystals on top with an anode of cadmium amalgam cast in the form of a rod. The firmness of the cadmillm amalgam made this possible. Two cells were made with a 4.7 percent amalgam, and seven others were made with a

${ }^{1}$ Zeit. für Instk. 2I, 33 (Igor) ; 2I, 65 (Igor).

21. c. 
I 3 percent amalgam. It had been shown by Jaeger that the use of the latter strength prevented the great irregularities observed below $15^{\circ}$. It was made clear by him also that the irregularities were due to the amalgam and not to a change in hydration of the sulphate. Moreover, he showed also that the solubility curve of the cadmium sulphate did not change below I $5^{\circ}$, but that the curve was continuous.

While carrying out the tests on our new cells it was unfortunate that we were unable to verify the results for the original inverted cells, but all of these had to be abandoned on account of the separation of the crystals from the amalgam by a thin film of gas. To avoid this happening again the cadmium amalgam rod cell was devised, and the new cells made in the upright form.

The original inverted cells were made in 1897 , but the tests on them were not published until Igoo. The delay in publication resulted from our desire to find a satisfactory explanation of the wide divergence from the German values. Since, for other reasons, further delay was impossible, the results were published pending a more thorough investigation. The tests on these cells were carried out with the same apparatus used by Callendar and Barnes, and described fully in other places. It will not be necessary, therefore, to describe the measurements, since the method of procedure was the same as previously used.

We found that our cells showed considerable divergence as regards their temperature changes of $\mathrm{E}$. M. F., and although our experiments were very carefully carried out and particular attention paid to the electrical readings, all our results were higher than the formula proposed by Jaeger and Wachsmuth. The cells were subjected to temperature changes between $15^{\circ}$ and $30^{\circ}$, and I $5^{\circ}$ and $0^{\circ}$, ample time being allowed for the attainment of steady conditions. Large changes were observed at $0^{\circ}$ in the cells containing the 14.7 percent amalgam, and much steadier and more consistent results were obtained with the other cells.

The changes in E. M. F., which we observed, varied between 0.0079 percent per degree for the cells with the 14.7 per- 
cent amalgam to 0.0054 percent per degree for the 13 percent amalgam, between the intervals of temperature $10^{\circ}$ and $28^{\circ} \mathrm{C}$. Our tests were unsatisfactory in so far as they offered us no explanation of our higher values. They showed us, however, that the cells with 14.7 percent amalgam gave a distinctly higher change than the other cells. Unfortunately, owing to the stress of other work, we were obliged to abandon any further attempts at this time.

Recently a number of tests have been carried out by us on various types of cells, which shows us that the divergence in the temperature coefficient is really due to the strength of the cadmium sulphate solution.

Four cells were constructed in the inverted form with the purest possible materials. New cadmium metal was used for the amalgam, which was the best supplied by Merck. Moist crystals of cadmium sulphate were used as before, and our cells differed from the original inverted cells only in having a I3 percent amalgam made from different cadmium metal. One of our new cells was made in the $\mathrm{H}$-form with a saturated solution in place of the moist crystals. Two of the cadmium rod cells tested in I9OI were also included, and in addition two cells supplied by the Weston Electrical Instrument Co. were subjected to temperature changes. These cells were lent to us by the Department of Electrical Engineering through the kindness of the director, Professor R. B. Owens, D.Sc. Jaeger and Lindeck have shown that these cells, with solution saturated at $0^{\circ}$ and therefore unsaturated at ordinary temperatures, have a very small temperature coefficient, which changes sign at about $20^{\circ}$. A maximum value of the E. M. F. occurs at about this temperature.

We, therefore, had three types of cells; six cells with moist crystals which ensured saturation of the adhering liquid at all temperatures; a cell with solution saturated at $20^{\circ}$ and no excess of crystals; and two cells with unsaturated solution.

We were unable to use the various pieces of apparatus hitherto employed for standard cell work in this laboratory, 
owing to their use in other investigations, but another arrangement was quite as accurate and reliable, although not so con venient. For a thermostat we had a large copper air-bath with double walls through which water could be circulated at different temperatures. Some of the cells were not suited for direct insertion in a water-bath, so that the present arrangement was really better than our former one. All of the cells were placed in this bath and connections made with the outside by means of carefully insulated wires leading to a paraffin block with mercury cup contacts.

The electrical readings were made on the Kelvin-Varley slide potentiometer used and described in previous investigations in this laboratory. The errors of the various coils were all less than I part in I0,000, and determinations of the errors agreed in all cases for the ror coils to a tenth of this amount. The resistance of the whole potentiometer was 100,000 ohms, and for reading the deflections with the vernier dial a Kelvin I00,000 ohm galvanometer was used. Our readings were in all cases accurate to I part in 50,000 at least.

Four Clark cells, kept in a water-bath, were read at the same time, and the values of our Weston cells were obtained in terms of them. Our method of measurement had the disadvantage of not being one of difference as formerly employed, but it had the advantage of direct comparison with the Clark cell without altering any connections.

Our first set of readings did not include the $\mathrm{H}$-cell, this cell being made specially for and included in a second set of readings undertaken solely to compare the various temperature coeffcients.

The following readings were obtained in comparing the Westons with the Clarks:

Of the Weston cells, Nos. 224 and 185 are the Weston Instrument Co.'s cells, $\mathrm{Cd}_{\mathrm{II}}$ is one of the cadmium rod cells, and $\mathrm{Cd}_{\mathrm{r} 6}, \mathrm{Cd}_{\mathrm{r} 7}, \mathrm{Cd}_{\mathrm{r} 8}, \mathrm{Cd}_{\mathrm{Tg}}$ are the new inverted cells.

In regard to the Clark cells, $\mathrm{X}_{2}$ is one of the five original cells made in 1895 and still in the possession of the laboratory. $\mathrm{X}_{44}, \mathrm{X}_{45}, \mathrm{X}_{46}$ are three new cells which were made in IgoI. 
Weston Cails

Temperature $19.9^{\circ} \mathrm{C}$.

\begin{tabular}{c|c|c|c}
\hline Cell & Pot. read. & Cell & Pot. read. \\
\hline 224 & 52993 & $\mathrm{Cd}_{16}$ & 52995 \\
$\mathrm{I} 85$ & 53002 & $\mathrm{Cd}_{17}$ & 52978 \\
$\mathrm{Cd}_{11}$ & 53003 & $\mathrm{Cd}_{18}$ & 52980 \\
- & - & $\mathrm{Cd}_{19}$ & 52983
\end{tabular}

Clark Chisis

Temperature $\mathrm{I} 4.96^{\circ} \mathrm{C}$.

\begin{tabular}{c|c|c|c}
\hline $\mathrm{X}_{2}$ & $\mathrm{x}_{44}$ & $\mathrm{X}_{40}$ & $\mathrm{X}_{46}$ \\
\hline $745^{\mathrm{r}} 7$ & $7453^{\circ}$ & $7453^{\circ}$ & $745^{28}$
\end{tabular}

A similar comparison was made at two other temperatures, and the values referred to the Clark cells. The following readings were obtained:

Weston Celis

Temperature $14.6^{\circ} \mathrm{C}$.

\begin{tabular}{c|c||c|c}
\hline Cel1 & Pot. read. & Cell & Pot. read. \\
\hline 224 & 53035 & $\mathrm{Cd}_{16}$ & 53042 \\
185 & 53040 & $\mathrm{Cd}_{17}$ & 53028 \\
- & - & $\mathrm{Cd}_{18}$ & 53030 \\
- & - & $\mathrm{Cd}_{19}$ & 53033
\end{tabular}

Clark Celis

Temperature $\mathrm{I} 4.4 \mathrm{I}^{\circ} \mathrm{C}$.

\begin{tabular}{c|c|c|c}
\hline $\mathrm{X}_{2}$ & $\mathrm{X}_{44}$ & $\mathrm{X}_{45}$ & $\mathrm{X}_{46}$ \\
\hline 74620 & 74630 & 74630 & 74630
\end{tabular}

A comparison of these three sets of readings will show that all of the inverted cells have the same coefficient for their relative differences are preserved thoughout the range of tempera. ture.

In working out the values of the cells we have taken for the Clark the value 1.43325 volts at $I 5^{\circ} \mathrm{C}$, and corrected for 
temperature by the formula $\mathrm{E}_{\mathrm{T}}-\mathrm{E}_{15}=-\mathrm{I} .2 \mathrm{O}(t-\mathrm{I} 5)-$ $0.0062\left(t-1_{5}\right)^{2}$, expressed in millivolts. This gives for the Weston Instrument Co.'s cells the values :

Weston CELLS

Temperature $27.9^{\circ} \mathrm{C}$.

\begin{tabular}{c|c|c|c}
\hline Cel1 & Pot. read. & Cel1 & Pot. read. \\
\hline 224 & 53052 & $\mathrm{Cd}_{16}$ & 53023 \\
$\mathrm{I} 85$ & 53057 & $\mathrm{Cd}_{17}$ & 53015 \\
- & - & $\mathrm{Cd}_{18}$ & 53015 \\
- & - & $\mathrm{Cd}_{19}$ & 53022
\end{tabular}

Clark Celis

Temperature $\mathrm{I} 4.6 \mathrm{I}^{\circ} \mathrm{C}$.

$\left|\begin{array}{c}\mathrm{x}_{46} \\ 74647\end{array}\right| \bar{T}$

The maximum value, about $20^{\circ}$, corresponds to the results obtained by Jaeger and Lindeck, who found

$$
\begin{aligned}
& \text { I.O1914 at } 14.6^{\circ} \mathrm{C} \text {. } \\
& 1.01916 \text { at } 19.9^{\circ} \mathrm{C} \text {. } \\
& \text { I.01907 at } 27.9^{\circ} \mathrm{C} \text {. } \\
& \text { I.OI886 at } 13.3^{\circ} \mathrm{C} \text {. } \\
& \text { I.OI884 at } 16.2^{\circ} \mathrm{C} \text {. } \\
& \text { I.OI886 at } 19.7^{\circ} \mathrm{C} \text {. } \\
& \text { I.01883 at } 29.9^{\circ} \mathrm{C} \text {. }
\end{aligned}
$$

The difference here in the absolute value is of course due to the fact that the value of the Clark cell assumed by the German authorities and used for reduction, is somewhat lower. It is given by Jaeger and Lindeck as I.4329r volts.

The cells with unsaturated solution are somewhat higher than those with saturated solution as Jaeger and Lindeck point out. According to our values at $19.9^{\circ}$, this difference amounts to 0.00027 volt, which is almost identical to the values 0.0002 I at $I 9.7^{\circ}$ and 0.00025 at $19.8^{\circ}$, taken from Table IV of Jaeger and Lindeck for their older cells.

The average change per degree for the inverted cell is 
found to be $0.005^{I}$ percent, which is lower than the value found before for the inverted cells with the I4.7 percent amalgam, but still in excess of the value for Jaeger's cells. The value agrees, however, with the value 0.0054 percent, obtained for the cadmium rod cells with a $\mathrm{I} 3$ percent amalgam.

The exceedingly small coefficient of the Weston Instrument Co.'s cells, and the lower values we obtained for our cells with I 3 percent amalgam led us to think that a cell with solution of constant strength saturated at ordinary temperatures, together with the 13 percent amalgam, would give us a coefficient less than the new inverted cells, and therefore more in agreement with the German values. Our $\mathrm{H}$-cell was therefore constructed with this in view and the second set of readings obtained to compare the coefficients of all the types. The following table contains the reading:

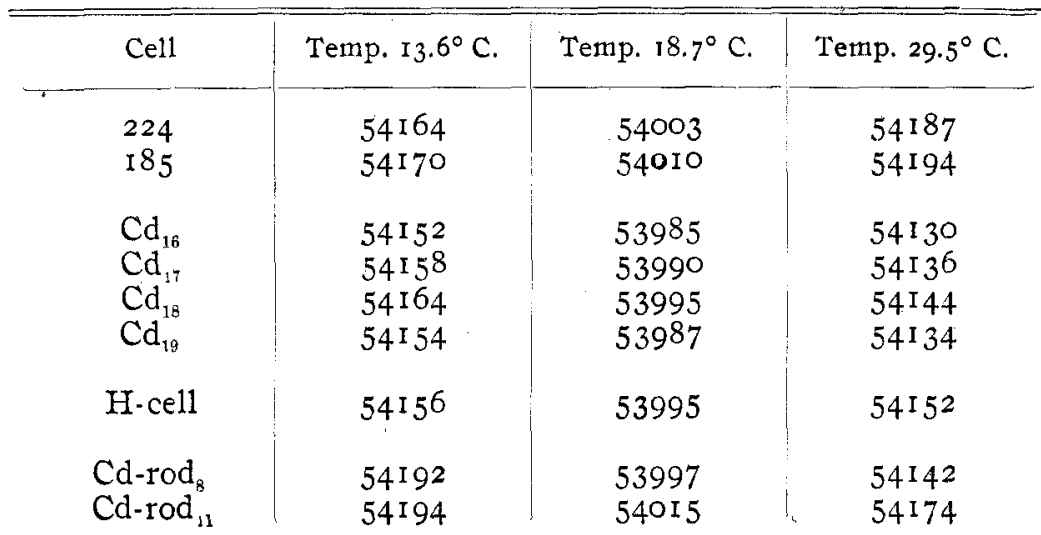

The following are the mean values for the different cells :

\begin{tabular}{|c|c|c|c|}
\hline Cell & $I 3.6^{\circ}$ & $18.7^{\circ}$ & $29.5^{\circ}$ \\
\hline Weston & 54167 & 54007 & 54 I9I \\
\hline Inverted & 54 I 57 & 53989 & 54136 \\
\hline H-cell & 54156 & 53995 & 54152 \\
\hline Cd-rod & 54193 & 54006 & 54 I 58 \\
\hline
\end{tabular}

In working out the temperature coefficient of the cells the value of the Weston cell for each of the three temperatures is 
taken by the comparison with the Clark and quoted from the previous tests. This was found necessary owing to the gradual change in the accumulator supplying the steady current to the potentiometer over the length of time, three days, occupied in taking readings. Six to eight hours was allowed at each point for the cells in the air-bath to take up a steady temperature.

It is worthy of note that the relative differences of the four inverted cells are maintained very closely. This is less satisfactory for the cadmium rod cells, but these cells are older and made with the old and possibly less pure cadmium metal. In addition $\mathrm{Cd}_{8}$ possessed a $\mathrm{I} 4.7$ percent amalgam and $\mathrm{Cd}_{\mathrm{TT}}$ a I 3 percent amalgam. They are both included in the mean for this type of cell, but it is seen that $\mathrm{Cd}_{8}$ has a larger temperature coefficient than $\mathrm{Cd}_{\mathrm{Ir}}$.

The average change between $I 3^{\circ}$ and $29^{\circ}$ from these observations is, for each type of cell, as follows :

\begin{tabular}{c|c}
\hline Cell & $\begin{array}{c}\text { Temperature change per degree. } \\
\text { Percent }\end{array}$ \\
\hline Weston Inst. Co. & Negligible \\
Inverted & 0.0058 \\
Cd rod & 0.0076 \\
H-cell & 0.00388
\end{tabular}

It is evident from these results that the divergence between the crystal cell and the H-cell with saturated solution is real, and has to do with the strength of the solution remaining constant in the latter case. The agreement of our $\mathrm{H}$-cell with the German cells, where an excess of solution is used, makes it appear probable that both these cells are similar. That is to say the solution probably remains of constant strength at all temperatures. The difficulty of preparing a saturated solution of cadmium sulphate is very great. The last traces of salt are dissolved with difficulty, and it is only after vigorous shaking for several hours that the solution can be made. Diffusion alone would result in the solution requiring an almost infinite time to become saturated. Even in the Clark cell with zinc sulphate, which is much less difficult to prepare, 
it has been shown that a period of two weeks was required for diffusion to take place on a change in temperature in one of the old forms of Board of Trade cell. In both our inverted and cadmium rod cells with the moist crystals the adhering solution is always saturated.

From the results of our experiments it is evident that cells with solution saturated at $0^{\circ}$ have practically no temperature coefficient; that cells with a saturated solution of constant strength have a temperature change of 0.0038 percent per degree, that cells with moist crystals and a $\mathrm{r} 3$ percent amalgam have a temperature change of 0.0055 percent, and that cells with moist crystals with a 14.7 percent amalgam have a temperature change of 0.008 percent per degree.

\section{Ratio of Clark to Weston}

The ratio of our Clarks to our first Weston cells in the inverted form and with the 14.7 percent amalgam was found to be I.40658. This value is a little lower than the latest values given for the cells in the possession of the Reichsanstalt, which makes it appear, in light of our recent work, that the inverted cells were too high. From the agreement of all the various types of Clark cells which we have made from time to time in this laboratory it is exceedingly unlikely that they are too low.

It is possible to obtain another value of the ratio from our new cells by the observations given in our first table.

If we take the mean of the four inverted cells at $19.9^{\circ} \mathrm{C}$, which is in practical agreement with the $\mathrm{H}$-cell, and compare this with the three new Clark cells, $\mathrm{X}_{44}, \mathrm{X}_{45}, \mathrm{X}_{45}$, we obtain the value

$$
\frac{\text { Clark at } 15^{\circ}}{\text { Weston at } 20^{\circ}}=1.40666 \text {, }
$$

after applying the small corrections for the potentiometer.

Cell $\mathrm{X}_{2}$, as before stated, is one of the five original "crystal" cells described fully by one of us, and used previously to obtain the ratio. It was found that this cell, as well as the other four, were a little too low when compared with all the other cells that were made at different times, which brought our original ratio 
from 1.40644 to $1.4065^{8 .}$ Comparing the observations in our first table, $\mathrm{X}_{2}$ is seen to be a little lower than the new cells by almost exactly the same amount as was previously found, for this reason we have omitted it from the mean in the present determination of the ratio. The mean value of the ratio obtained at the Reichsanstalt is given by Jaeger and Lindeck ${ }^{2}$ as I. 40665 , which is coincident with our value.

We find it probable from a number of considerations that our original inverted cells were a little too high. Ourcadmium rod cells, which were made with the first cadmium metal, are also a little high when compared with the new cells.

In conclusion we may remark that it is a matter of small moment which cell, the Clark or the Weston, is adopted as an official standard, since the ratio of the one to the other is known so closely. Both cells have points to recommend them for different types of work, but it is evident that the Clark cell will retire more completely into the laboratory as time goes on, leaving to the Weston cell the more active part of a general working standard.

McGill University, Jan. 2, 1904

${ }^{1}$ See Phil. Trans. I99A, I49 (1902), for full history of these cells.

${ }^{2}$ Loc. cit. 